\title{
Twenty Years of Democracy and Digital Poverty: Technology Challenges Experienced by Women in the Chris Hani Municipality of the Eastern Cape Province of South Africa
}

\author{
Grasia Chisango \\ Zandi Lesame \\ University of South Africa \\ graciac@yahoo.co.uk \& lesamnc@unisa.ac.za
}

Doi:10.5901/mjss.2014.v5n27p1553

\begin{abstract}
South Africa has introduced a few telecommunications policy changes and market reforms over the past two decades aimed at ensuring universal access to telecom services. However, this has not materialised. This study reveals the extent of digital poverty in the Eastern Cape, especially among women. The research was undertaken between 2011 and 2013, and focused on whether women in the Chris Hani municipality of the Eastern Cape have access to and use ICT and, if so, what the women use ICT for. In the Eastern Cape there is no extensive access to ICT. Moreover, the Eastern Cape has high poverty levels and deployment of ICT in this province could help to reduce poverty and improve the high illiteracy levels. This article describes the purpose of the research and background to the study, revisiting the South African ICT policy of universal service, assessing how this policy has not been effectively implemented in the Eastern Cape, and also providing a critical evaluation of how lowincome women residing at the Chris Hani municipality sampled for this research have not benefitted economically, educationally or socially from the few ICT services available to them. It appears that South ICT policy makers need to reconstruct current policy to accommodate the rural poor, such as the women of the Eastern Cape. The results of this study indicate that access to ICT could also create opportunities for the women in Chris Hani municipality to use technology to improve social relations among family members who are located far apart as most men work away from home. Also, ICT could offer women communication tools to demand better social services from unaccountable government officials who have failed to deliver community development services to these communities.
\end{abstract}

Keywords: Eastern Cape Province; South Africa; digital poverty; education; multidimensional development; "the Fourth World"; the network society; information society; poverty; unemployment

\section{Introduction}

Since the concept of the information society was developed in the seventies, the correlation between access to information and poverty has been widely acknowledged. According to Flor (2001), information leads to opportunities that generate resources, access to information leads to access to resources, and access to information leads to opportunities that generate resources. This in turn means that lack of access to ICT leads to lack of access to information and resources.

This study sought to investigate and highlight technology access and use by rural women in the Chris Hani district municipality (CHDM) in the Eastern Cape of South Africa. Technology can be a useful tool for a number of stakeholders ranging from education authorities, policy makers and implementers to women support groups. These stakeholders could devise interventions and strategies to assist rural women to improve their lives by using technology to gain education and skills. Technology connects the world, is used as a tool to conduct business and stimulate social networking as well as to advance the economic development of nations. Rural South Africa is faced with difficulties in accessing ICT because most of these rural areas have no access to ICT infrastructure, despite progressive ICT regulations and policies, for example, the much lauded Broadband Policy, developed in November 2013 and whose objective it is to "create opportunities and ensure inclusion" of "all" South Africans to the existing communications network (Carrim, 2013).

Government policies such as this broadband policy have as yet not been wholly implemented across the country as the ICT infrastructure has, so far, not been deployed by the responsible government agencies, for example the Universal Service and Access Agency of South Africa (USAASA). Women in rural areas are an economically marginalised group who are voiceless, and it is the duty of researchers to bring to light the plight experienced by rural women so that the challenges which they face become known and can then be addressed through appropriate ICT 
deployment and delivery of educational facilities to those who lack them.

\section{Background to the Study}

The Eastern Cape historically lacks development and is characterised by poverty. The province requires multidimensional development aimed at improving all areas of socio-economic development, including deployment of ICT in schools and other institutions to improve education and health care, and to create employment and reduce poverty.

\subsection{The need for multi-dimensional development in the Eastern Cape}

Development is "a multi-dimensional process involving major changes in social structures, popular attitudes and a national condition of life from unsatisfactory to satisfactory" (Servaes, 1999:77). As the results of this study indicate, life for many individuals, women in particular, residing in the Eastern Cape is unsatisfactory as they live in poverty and are without work and income. It is critical, therefore that government implements development plans and programmes aimed at improving the lives of ordinary citizens in the province. Multi-sectoral development should be aimed at the advancement of sectors such as education, health, and e-government that will bring government services to citizens with the click of a mouse. With regard to the economic situation, work opportunities should be created to reduce high unemployment. Additionally, ICT, when accessible to individuals, is viewed as instrumental in this multi-dimensional development. Information is necessary for development to occur and ICT allows access to and sharing of information. Further, ICT allows government to communicate with civil society to advance and introduce development projects to the public. Technology supplements mass media such as radio, television and print media for development communication. In a developing country, the dissemination of information to its citizenry essential, for instance information about new fertilisers, seeds, public health and education. The process of education is related to information dissemination and ICT disseminates development information to ICT users. Media (ICT) can perform the communication and informationtransfer function for development purposes. To invest in education is productive because an educated labour force is a source of productivity and development. It is therefore important that ICT be deployed across the whole Eastern Cape, not only in the Chris Hani municipality.

Figure 1: South African Provincial Boundaries

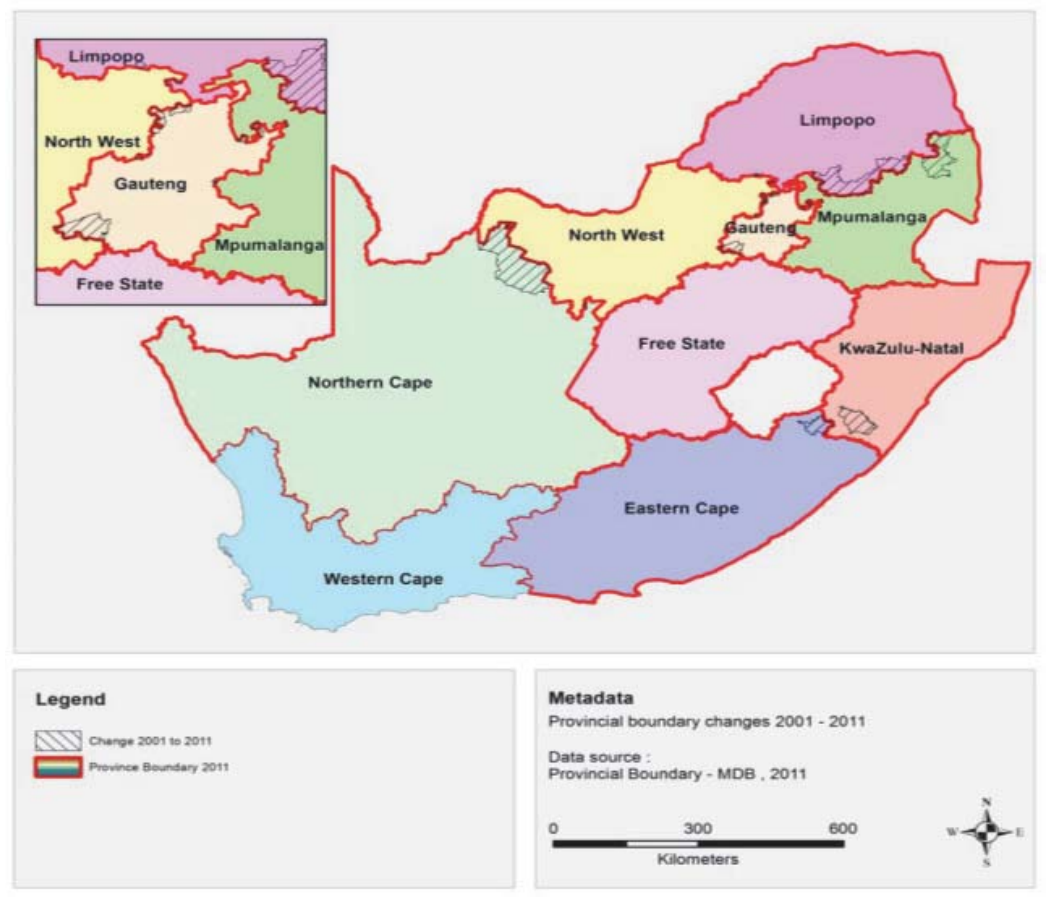

Source of Figure 1: Statistics South Africa Census Report $(2011,10)$ 
The Eastern Cape had a population of six and half million people in 2011. It is important to note that many people from the Eastern Cape migrate to Gauteng to seek work, as there are economic opportunities in Gauteng that cannot be found in the mostly rural provinces like the Eastern Cape.

Table 1: Total Population by Province, Censuses 1996, 2001 and 2011

\begin{tabular}{|l|c|c|c|}
\hline Province & Census 1996 & Census 2001 & Census 2011 \\
\hline Western Cape & 3956875 & 4524335 & 5822734 \\
\hline Eastern Cape & 6147244 & 6278651 & 6562053 \\
\hline Northern Cape & 1011864 & 991919 & 1145861 \\
\hline Free State & 2633504 & 2706775 & 2745590 \\
\hline KwaZulu-Natal (KZN) & 8572302 & 9582129 & 10267300 \\
\hline North West & 2727223 & 2984098 & 3509953 \\
\hline Gauteng & 7834125 & 9388854 & 12272263 \\
\hline Mpumalanga & 3123869 & 3365554 & 4039939 \\
\hline Limpopo & 4576566 & 4995462 & 5404868 \\
\hline South Africa & $\mathbf{4 0 5 8 3 5 7 3}$ & $\mathbf{4 4 8 1 9 7 7 8}$ & $\mathbf{5 1 7 7 0 5 6 0}$ \\
\hline
\end{tabular}

Source: Statistics South Africa Census Report $(2011,14)$

Table 1 indicates that the Eastern Cape has the third-highest population in South Africa, after Gauteng and KwaZuluNatal. However, the Eastern Cape has the second-lowest average annual household income after Limpopo, and Gauteng has the highest average annual household income (see Figure 2).

The challenge facing the South African government therefore, is to improve the economic situation of the Eastern Cape by creating work opportunities with the sole purpose of alleviating the state of high unemployment which has resulted in a low average annual household income as indicated in Figure 2. It will take the Eastern Cape several years to bridge the economic chasm that currently exists between this province and other provinces such as Gauteng and the Western Cape, where the average annual household income is much higher in comparison to that of the Eastern Cape. Creation of work opportunities in the Eastern Cape could help to generate an income for many households - an economic improvement which could contribute to better access to and use of ICT in areas of the Eastern Cape where such ICT is available.

Figure 2: Average Annual Household Income by Province

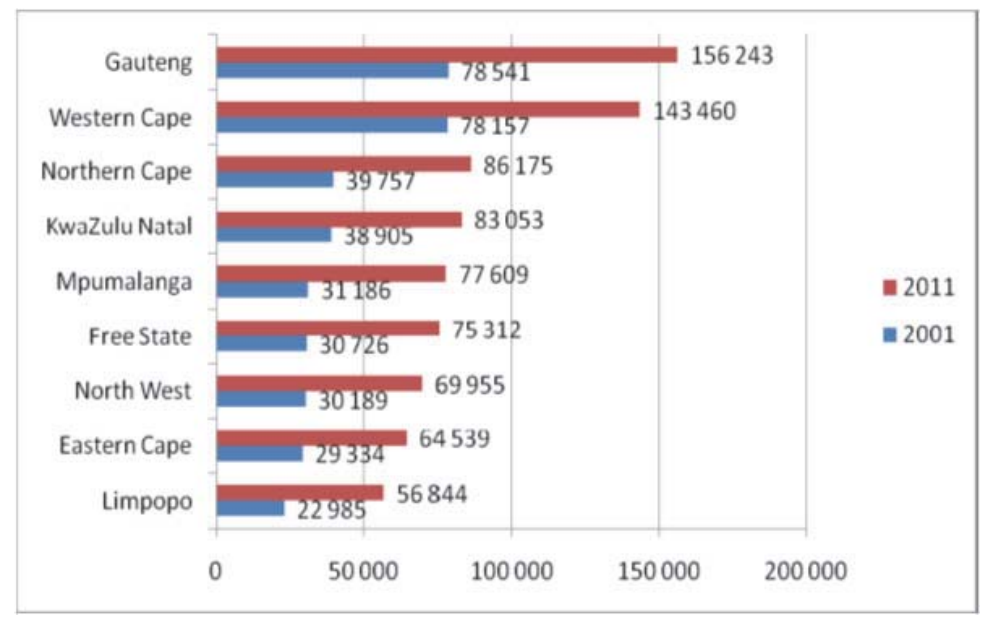

Source of Figure 2: Statistics South Africa Census Report $(2011,42)$.

Closely linked to the challenge of low average annual household income is the challenge of low levels of ICT access nationally, especially access to computers and landline telephones. 


\subsection{Twenty years of democracy: Technology access in South Africa and digital poverty in the Eastern Cape}

The state of access to ICT in South Africa is summarised in Figure 3, which indicates that access to computers and telephones should be improved drastically if people are to have access to information because computers play an instrumental role in diffusing innovations and information among people. Figure 3 also shows that access to mobile phones has increased rapidly in South Africa, as well as access to television; but access to computers at home is very low which is a concern for the creation of an information society as computers and networks (which are characteristics of a network society and information societies) influence information production and transfer. How can people produce information and share it with others if they have no computers? The challenge facing national government is thus to increase access to computers and landline telephones so that the status of South Africa as an information society is improved.

Figure 3: Percentage of South African households with access to telecommunications - 2001 to 2013

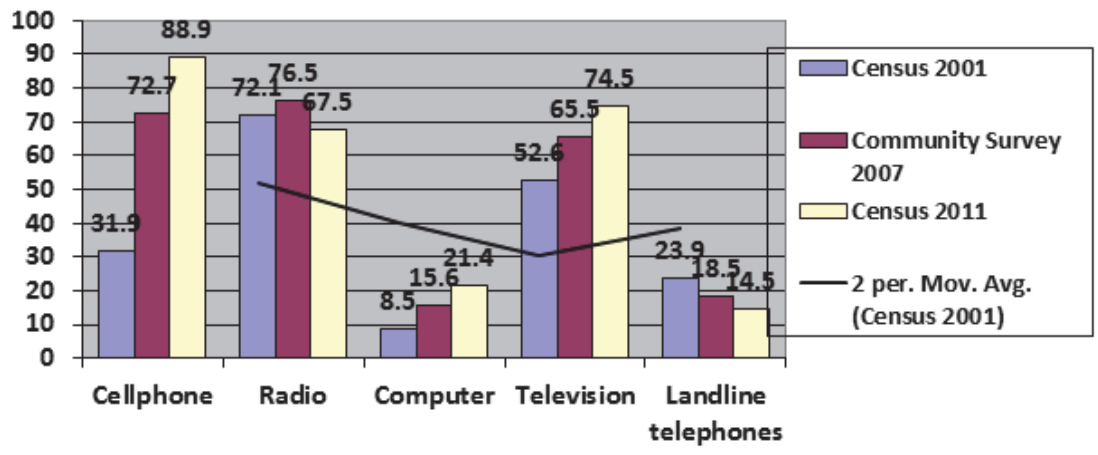

Source: Haffajee (2014:21)

The information society is about information production (and selling) and sharing; it goes beyond communicating with others through technology or socialising on social networks. South Africa is not yet at that stage since most South Africans have no access to a computer at home. In Africa, many countries including Mauritius are ahead of South Africa in becoming information societies. Mauritius completed its conversion process from analog to digital broadcasting in 2013 while South Africa is still grappling with this process.

Another recent study which revealed the state of the digital divide and digital poverty in South Africa, and not only in the Eastern Cape, is the South African Network Survey (2013; summarised in Figure 4), which published the following information regarding computer networks and their usage in South Africa:

- A total of $71 \%$ of South African use their mobile phones to access the internet.

- These users use social networks rather than the internet for information.

- $22 \%$ of South Africans use the internet daily.

- $62 \%$ spend more than R1,00 a day on using a mobile phone.

- About 2 million South Africans use internet access only for social networks.

- $75 \%$ of social media users use the internet daily.

- Only $35 \%$ of people who do not use a social network use the internet.

- Three of four internet users have accounts at one or more social networks. 
Figure 4: The South African Network Survey results (2013)

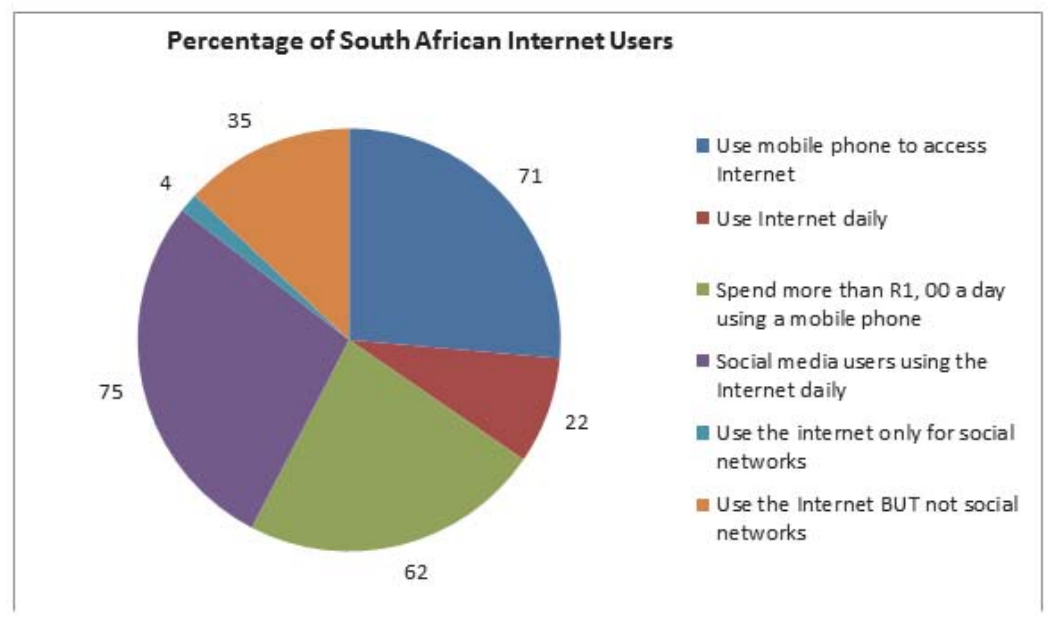

Source: The South African Network Survey (2013), in City Press (2013)

The survey also disclosed that most South Africans who use the internet -

- can speak English;

- are currently at school, university or work; and

- have university training.

The survey also revealed that South Africans who are not internet users -

- cannot easily read or write English;

- are older than 44 ;

- are very poor; and

- live in a rural area.

In line with the findings of this 2013 survey, the current study established that the residents of the Chris Hani district municipality, in the sampled rural areas, form part of the South African population identified by the South African Network Survey of 2013 as "not being an internet user", "very poor", "cannot easily read or write English" and "lives in a rural area". The results of this study support this information as this study has found similar characteristics in the sampled residents in Chris Hani municipality.

One of the important and interesting pieces of information revealed by South African Network Survey (2013) is that internet users access internet services from mobile phones and not from computers. Additionally, uneducated, older and poor people who reside in rural areas do not use the internet. Often, those using the internet generally use it to access social networks and not to find useful information that could improve their lives. In a network society, information seeking and usage is crucial for personal and national development. The fact that those South Africans who do not use the internet for seeking and sharing information is a cause for concern as it is another indicator that they are not interested in developing the self and communities. Thus, although users might be connected to each other via social networks, they do not seem to share constructive and development information via these networks.

\subsection{The "Fourth World" and the digital divide in the Eastern Cape}

The concept of the "Fourth World" was coined by Castells (2000) to refer to populations secluded and remote from the network society. Inhabitants of the "Fourth World" do not make use of technology networks and prefer traditional ways of life. The digital divide and digital poverty are characteristics of the "Fourth World".

According to some digital divide policy analysts, problems with ICT inequality date back to the late 1960s or early 1970s (Selwyn, 2004; Kucukaydin \& Tisdell, 2008). In the 1960s up to the 1980s scholars and leaders of international organisations and states began evaluating different factors contributing to the national and international technology and information gap; for example, one was the MacBride Commission, appointed by the general conference (held in 1976) of the United Nations Educational, Scientific and Cultural Organisation (UNESCO), with the main aim of identifying challenges and inequalities in the flow of information between nations (Oosthuizen \& Qakisa, 1996:125-126). The digital 
divide thus became a topic of debate in the early-to-mid 1990s (Selwyn, 2004). Although there was already an inequity regarding information access and computer ownership, the term "digital divide" was not widely used until former US President Bill Clinton and his deputy Vice President Al Gore used it in 1996 (Selwyn, 2004). In the 1990s, countries such as the United Kingdom (UK), France and the United States (US) witnessed a subtle shift towards socially-inclusive policy agendas that sought to combat global social exclusion by reviewing policies towards establishing an "inclusive society".

The digital divide thus refers to "significant demographic gaps in computer and Internet access and usage which scholars and analysts have observed in the ICT sector since 1995" (Hacker \& Mason, 2003:99). The digital divide can also be defined as "the gap between access of individuals, households, organisations, countries and regions at different socio-economic levels to ICT and internet usage" (Lesame, 2005:3). Thus, the digital divide not only refers to the gap between the affluent, urban information haves and the impoverished rural information have-nots but also to the digital and ICT chasm between the peripheral African continent and the developed world. Van Dijk (1999:153) refers to an ICT "usage gap" where more educated people with digital skills use computers, ICT facilities and the internet more than those less educated, in any country, resulting in digital divide gaps known as "knowledge gaps" or "information gaps" (Lesame, 2013). Another aspect of the usage gap is the "Matthew effect" (Van Dijk, 2006), which means that "the rich get richer" and "the poor get poorer" as a result of using ICT to access opportunities, economic and development resources. The rich acquire more information than "the poor" because they can afford to purchase ICT (technology) and ICT content (data, information, news and entertainment) while the poorer members of society are unable to afford ICT (Lesame, 2013).

\subsection{Theoretical approaches employed globally to deal with the digital divide}

Countries deal with the digital divide in different ways. One way is by implementing ICT policies aimed at deploying the ICT infrastructure nationwide. For example, in Thailand mobile internet access is widely available and contributes to closing the digital divide (Lesame, 2013).

According to Kucukaydin and Tisdell (2008:1), "equal distribution of educational digital opportunities is desirable". Thus many policymakers, politicians, CEOs, scholars and educators concerned are exploring the positive effects in bridging the digital divide through education. This suggests that there should first be awareness and solving of societal inequalities for the digital divide to be bridged. Kucukaydin and Tisdell (2008:3) perceive "the digital divide discourse and its popularization as a product of ideological hegemony". While different stakeholders in societies, including government leaders, are preoccupied with bridging the digital divide, they should also be concerned about reducing structural and historic social and economic inequalities and contribute towards changing hegemonic tendencies in societies which maintain the status quo.

Scholars, ICT industry analysts and government officials approach the digital divide in different ways and some of these practical approaches of addressing the digital divide are the following (Sassi, 2005:687-694):

- Technocratic approach: This refers to the differences in internet usage within countries, even in ICT-advanced countries. These could include internet access disparities between urban and rural areas within a country. The solution to this challenge, within the South African context - including the Eastern Cape, lies in government ICT policy formulation and implementation (which is the government's primary duty) while the private sector could assist by investing in the deployment of the ICT sector infrastructure. Both government and the private sector should collaborate in deploying a well-developed ICT backbone by pursuing and implementing ICT policies such as universal service and universal access to ICT, as well as liberalising or deregulating the telecommunications sector to speed up ICT delivery processes (Lesame, 2000; 2013).

- Social structure approach: This perspective maintains that the digital divide is a result of social structure historical imbalances, for example gaps between the "information-rich" and the "information-poor", the rich and the poor, and other groups. This perspective also rings true for South Africa because the economic imbalances are historically based. In this approach it is not expected that the fundamental inequalities of social stratification which are endemic throughout post-industrial societies will be overturned (Sassi, 2005).

- Information structure and exclusion approach: This approach is based on the previous two approaches and asserts that the digital divide comprises two processes. This approach is also relevant in describing the urbanrural ICT imbalances of the Eastern Cape because it can be argued that the absence of an ICT infrastructure in most parts of the Eastern Cape illustrates exclusion of the province from the South African network society, thus denying the Eastern Cape resources such as information and advanced educational facilities which could be used to empower the people of that province. 
- Modernisation and capitalism (M\&C) approach: According to this approach, "there is a connection between modernisation and information technology, the latter assisting in controlling and managing very complex modern societies. The increase in information and communication can be explained by, among other factors, expansion of scale, the growing differentiation and division of labour, the rationalization of the economy and culture and social, and cultural individualization" (Manuel Castells' Network Society Wikipedia, 2013). The industrial system and the network society are dependent on ICT to manage the production and flow of information, and capitalism plays a significant role in these processes as it contributes to the creation or manufacturing of technology, employment of cheap labour and other economic activities and hazards that promote economic imbalances in many countries. According to Castells (2000), the industrial age has passed out into the information age. This historical change is brought about by the advent of new communication technologies. Society remains capitalist, but the basis of the technological age has changed from energy to information. For people to be active in society and participate in self-development and community development through the use of information, they have to be connected to networks, otherwise they remain powerless and unable to participate in economic activity.

The lesson that could be learnt from this approach, is that the Eastern Cape should be industrialised and modernised because ICT is mostly found in urbanised and modernised societies. At present, the province is more than $60 \%$ rural (as indicated by Figure 5), a state of affairs that needs drastic transformation if the province is to accommodate an ICT infrastructure. A traditional and rural Eastern Cape will make it difficult for any stakeholder prepared to deploy ICT in that province to do so. In other words, the Eastern Cape requires multi-dimensional development and not only ICT deployment for the citizens of the province to improve their lives. This is primarily the responsibility of government.

Figure 5: A map of Eastern Cape showing district and local municipalities

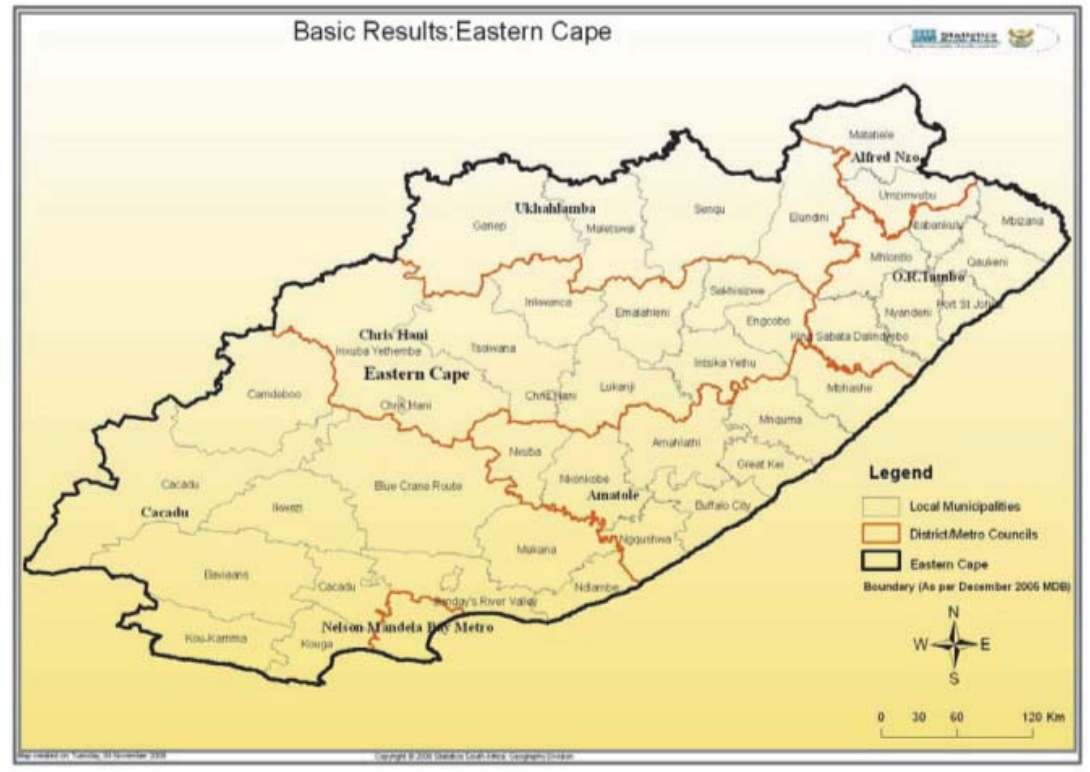

Source: Statistics South Africa Community Survey 2007 (Permission to reproduce graphic obtained from the Eastern Cape Development Corporation by Chisango - East London Strategy Manager in 2013).

In South Africa, 25, 6\% of the adult female population are illiterate (Hilbert, 2011). A high illiteracy rate among women, a digital divide, poverty and digital poverty are common in the Eastern Cape and are challenges that the South African government (local and national) has failed to address in 20 years of democracy.

\subsection{The digital divide, poverty and digital poverty in the Chris Hani municipality}

The Asian Development Bank defines poverty as the deprivation of essential assets and opportunities to which every human is entitled (Flor, 2001). Every citizen is entitled to live near basic education and health services. Poverty is thus 
better measured in terms of "basic education, health care, nutrition, water and sanitation, as well as income, employment and wages" (Flor, 2001:2). According to Spence (2010), ICT cannot solve poverty on its own but can contribute to the processes that lead to poverty reduction and achievement of other millennium development goals (MGDs) (United Nations Millennium Development Goals, 2009). Further, poverty is widely recognised as multidimensional, encompassing food security, health, education, rights, security and dignity (Spence, 2010). Therefore, in order to address poverty and eliminate it, all these elements should be improved in society if people's lives are to change for the better.

Poverty among women also represents a major barrier to ICT adoption in addition to cultural factors, such as early marriage, teenage pregnancy, child labour, thus creating a gender digital divide (Kwapong, 2007). It is not only poverty which is a barrier to ICT use among women, but also "illiteracy, lack of training and skills, and irregular or non-existent power supplies act as significant barriers" (Solidarity for African Women's Rights Policy brief for $14^{\text {th }}$ Ordinary African Union Summit 2010:9). The gender digital divide refers "to gender disparities in terms of access, control and content of information and communications technologies (ICT), as well as the necessary capacities to use them" (Mottin-Sylla, 2005:15). The digital divide results in digital poverty, which exacerbates other social ills including a high unemployment rate and poverty, which are prevalent in the Eastern Cape.

It is against this background that an exploratory qualitative study, using face-to-face interviews and focus group interviews, was undertaken for this research, to provide a working knowledge and understanding of the pertinent issues around women and the challenges they face in their usage of ICT in the CHDM. This research was undertaken to provide input that will inform current and future intervention strategies to improve women's access and use of ICT in the Eastern Cape.

According to the South African Government Gazette No 26734 (2004), if every South African is to participate effectively in the global economy, no one should be socially excluded and ICT should be made accessible to everyone. It is against this background that this study focused on the challenges faced by the sampled rural women in their use of ICT and the quest to identify possible solutions to their challenges.

Situated at the centre of the Eastern Cape, the Chris Hani district municipality (CHDM) is categorised as a C2 municipality, i.e. a municipality that is a "water service provider" (The Municipal Infrastructure Investment Framework/MIIF for South Africa 2011:10). Municipalities classified as category C2, indicate "a largely rural character and low urbanisation rate as well as limited municipal staff and budget capacity" (McCann, 2005: 3).

In this study, the research focused on the following CHDM local municipalities:

- Intsika-Yethu (which is a Xhosa word meaning "Our Foundation"), consisting of Tsomo and Cofimvaba rural towns (with several villages around each semi-rural town); and

- Emalahleni (which is a Xhosa word meaning "Place of Coal'), made up of Indwe, Lady Frere and Dordrecht (small rural towns also surrounded by and serving several villages) (Integrated Development Plan Review: Chris Hani District Municipality, 2010/2011).

These two local municipalities, which are under the CHDM are classified as B4, meaning that they are all rural areas where subsistence farming is mainly the mainstay of the local economy (McCann, 2005).

This study narrowed its focus on women who lived in the selected local municipalities, i.e. Intsika-Yethu and Emalahleni local municipalities during 2012 and 2013. The research mainly focused on women support group leaders, municipal mayors and high school girls from each municipality. It was reasoned that this group of women would be aware of the technology challenges facing women in their particular municipalities since they were familiar with the area and resided in the locality.

\section{Research Objectives}

The aims of the study were to:

- determine the level of ICT access and use by rural women in the CHDM;

- establish the rural women's purpose of using technology;

- identify challenges that rural women face in their use of ICT; and

- establish possible measures which can be used to address the problems faced by rural women in ICT usage.

\section{4. $\quad$ Research Questions}

The study answered the following research questions:

a. What is the level of ICT access and use by rural women in the Chris Hani District Municipality? 
b. What do rural women in the Chris Hani District Municipality use ICT for?

c. What are the challenges faced by the women with regard to their use of ICT?

d. Which possible measures could be used to address the problems faced by rural women in ICT usage?

\section{Research Methodology}

A qualitative approach was employed to collect data from the participants (Chisango, 2013). In-depth, face-to-face interviews and focus group interviews were conducted to obtain data from the respondents.

\subsection{The research design and research methods}

Qualitative research allows the researcher to probe the participants through in-depth, face-to-face interviews and thus gain a deeper insight into the phenomenon under study and other hidden issues related to the challenges faced by rural women in their use of ICT. Qualitative research "creates new concepts and emphasise constructing theoretical interpretations" (Neuman, 2006:15), thus the researcher does not only focus on a specific question, but considers the theoretical and philosophical paradigm in an inquisitive manner with an open mind (ibid.). This is relevant to this study because it allows the researcher to keep on probing the informants through in-depth, face-to-face interviews and get a deeper insight into the phenomenon under study and other hidden issues related to the challenges faced by the rural women in their use of ICT.

This qualitative approach gave the researcher the opportunity to investigate ICT usage by women in the selected rural municipalities under the CHDM. The participants in the study included two local municipal mayors, two women support group leaders and high school girls. In-depth, face-to-face interviews and focus group interviews were conducted with this group of women.

The two selected municipalities share the same characteristics; they are largely rural and rely on subsistence farming (McCann, 2005). Furthermore, the study was conducted in only two municipalities to cut down on costs involved in the study and to make the collection and interpretation of data manageable. Moreover, a case study method was used in this study which enabled the researcher to select a small geographical area and a limited number of individuals as the subjects of the study (Zainal, 2007).

\subsection{Execution of the research design}

This study sought to explore the technological challenges faced by rural women in the Eastern Cape, and how these challenges can be resolved. In-depth interviews were used to collect data from the respondents. In-depth interviews allow the researcher to pursue or to probe specific topics raised by the respondents giving deep insight on the topic under study. The researcher also used focus group interviews to collect data. Focus group interviews were conducted at high schools, that is, two different groups, each from one municipality of the two selected municipalities - Intsika-Yethu and Emalahleni. Focus group interviews were conducted at Gcinubuzwe senior secondary school and at Cofimvaba senior secondary school. In-depth interviews were conducted with the Intsika-Yethu municipality mayor and with the Emalahleni local municipality mayor. The Tsomo and Emalahleni women support group leaders were also interviewed.

\subsection{Validity and reliability}

To ensure validity, the researcher, with the help of a translator, used the participants' home language to interview participants who were not comfortable speaking English. A digital voice recorder was also used. This was done to ensure that the informants' responses were accurately captured. Respondent responses were recorded with an ipad and notes also witten in a notebook.

\subsection{Pilot study}

A pilot study was conducted with the aim of ascertaining the validity and reliability of the research instruments before the implementation of the data gathering tools (White, 2002). The pilot study tested the interview schedule and questions that were unclear to the selected pilot group (school learners and government officials), were make clear in the final interview schedule. The major reason for conducting a pilot study is to ascertain the overall feasibility of the study, test the data collection instruments before implementation, identify any logistical problems that could negatively affect the main study 
and also test the data analysis procedures.

The pilot study was undertaken in one of the local municipalities - Engcobo - which consists of All Saints and Clarkebury (Integrated Development Plan Review, 2010/2011). The municipality selected for the pilot study was not one of the two local municipalities selected for the main study. The research participants were made aware of the pilot study in writing.

\subsection{Target and accessible population}

This study focused on a population of rural women in the Eastern Cape, in particular rural women in the Chris Hani district municipality.

Accessible population refers to "the units of analysis in the target population to which researchers have access" (Du Plooy, 2009:51). This research only focused on women who were economically active. The research also focused on women from two local municipalities, Intsika-Yethu and Emalahleni, within the Chris Hani district municipality. The researcher identified units of analysis to include in the study. According to Babbie and Mouton (2010:84), units of analysis refer "to what of a study: what object, phenomenon, entity, process, or event you are interested in investigating". The units of analysis in this study were the individual women.

\subsection{Data analysis procedures}

The researcher used the thematic analysis approach to analyse the collected data. In this study, data was arranged into themes related to the sub-questions for analysis. The interviews were recorded on a digital voice recorder and transcribed into writing for the data analysis and presentation.

\subsection{Ethical considerations}

Research ethics are defined as the principles guiding the research, from the beginning to the completion of the study (Bryman, 2012). In this study data was collected from human subjects through in-depth interviews and focus group interviews. The researcher sought permission from the Department of Education and school principals before collecting data from the focus groups at high schools.

The subjects, that is, women and high school girls, were told about the nature of the study and they could choose whether to participate or not. The researcher also sought permission to interview government officials and women support group leaders through written letters. Each participant signed and dated a letter indicating their agreement to participate (Leedy \& Ormond, 2005), that is, they provided their informed consent. If the participants agreed to participate and then felt that they wanted to withdraw, they were free to do so. Participants were guaranteed anonymity to protect their confidentiality.

\section{Thematic Analyses and Discussion of Findings}

The study aimed at examining the technological challenges faced by rural women in the Eastern Cape, with a view to propose solutions towards addressing these challenges. This study focused on Emalahleni and Intsika-Yethu local municipalities. The research findings are discussed in terms of the themes drawn from the sub-research questions that guided the study. The following discussion focuses on the findings generated from the data collected through focus group interviews and in-depth interviews.

\subsection{Theme 1: Knowledge and use of information and communication technology for women's personal, business and agricultural development}

This theme sought to bring to light the level of ICT knowledge among Emalahleni and Intsika-Yethu women. Awareness of ICT affects the uptake and usage of ICT in society. From the in-depth interviews conducted, it emerged that most of the women in Emalahleni and Intsika-Yethu municipalities were aware of ICT, but the knowledge of using technology was limited in both municipalities. Respondent 3, a women support group leader from Emalahleni, stated that women in agriculture and development projects such as poultry, catering and pig farming, mainly use mobile phones which allow instant communication. However, they cannot access the Internet, which is required to access market information for their produce. Some of the women from both municipalities lack ICT skills to search, select and process information. They also 
lack ICT strategic skills, that is, the ability to use the computer and network sources to improve their position in society. Television, mobile phones and the radio are commonly used in both Intsika-Yethu and Emalahleni municipalities. Other ICTs, such as laptops, printers and facsimile machines are mainly used in government offices and it is only government employees who use them at work. However, most people in both municipalities have limited ICT skills knowledge. These findings clearly support Van Dijk (2006)'s analysis of the access model, that is, the digital skills access gap, which is a result of differences in levels of education and income (Van Dijk, 2006). Table 2 summarises some responses from the respondents in this study:

Table 2: Selected 10 verbatim responses from the interviewees

\begin{tabular}{|c|c|c|}
\hline Respondent Number and Comment & $\begin{array}{l}\text { Respondent Job } \\
\text { Description or } \\
\text { School Level }\end{array}$ & $\begin{array}{l}\text { Name of Municipality } \\
\text { where Respondent } \\
\text { resides }\end{array}$ \\
\hline $\begin{array}{l}\text { Respondent 1: } \\
\text { "Those who have access to these resources they do not know how to fully utilise } \\
\text { these resources, they have a challenge of the background knowledge on how the ICT } \\
\text { infrastructure can assist them". }\end{array}$ & Government leader & $\begin{array}{l}\text { Intsika-Yethu } \\
\text { Municipality }\end{array}$ \\
\hline $\begin{array}{l}\text { Respondent 4: } \\
\text { "Most women afford the cell phone for making calls and SMS, very few people are } \\
\text { able to use the Internef". }\end{array}$ & Government leader & Emalahleni Municipality \\
\hline $\begin{array}{l}\text { Respondent 1: } \\
\text { "The concept of ICT is fairly new and is not moving as fast as one would wish, there } \\
\text { is not much that is being done by those with access to promote the use of ICT to } \\
\text { other women who are not well versed on the use of ICT, so it is moving very slowly to } \\
\text { transfer the usage of ICT skill". }\end{array}$ & Government leader & $\begin{array}{l}\text { Intsika-Yethu } \\
\text { Municipality }\end{array}$ \\
\hline $\begin{array}{l}\text { Respondent 4: } \\
\text { "Emalahleni is a deep rural area, so computers, laptops and cell phones are easily } \\
\text { available at government offices"; therefore "women who are not working in any } \\
\text { government setup are only limited to the cell phone, some do not even have the cell } \\
\text { phone, remember one has to buy the cell phone". }\end{array}$ & Government leader & Emalahleni municipality \\
\hline $\begin{array}{l}\text { Respondent 3: } \\
\text { "ICT centres are not yet functional. Previously, there were no ICT centres in, making } \\
\text { it difficult for the dwellers to access ICT services, hence travelling to } \\
\text { Queenstown".[Queenstown is the town of Lukhanji in the Xhosa language] }\end{array}$ & Government leader & Emalahleni Municipality \\
\hline $\begin{array}{l}\text { Respondent/s in focus group interviews: } \\
\text { "Some pupils lack computer skills" and "lack of computer skills make it difficult for us } \\
\text { to easily adapt in this world of ever changing technology". }\end{array}$ & School learners & $\begin{array}{l}\text { Cofimvaba Senior } \\
\text { Secondary School } \\
\text { (SSS) and Gcinubuzwe } \\
\text { SSS }\end{array}$ \\
\hline $\begin{array}{l}\text { Respondent 2: } \\
\text { "Teenage pregnancy is an issue affecting the girl child, and this creates the gender } \\
\text { digital divide because these kids drop out of school". "There is also drug and alcohol } \\
\text { abuse in the area. Pupils drop out of school where ICT skills are taught and they } \\
\text { become part of the information have-nots in society". }\end{array}$ & $\begin{array}{l}\text { Women support } \\
\text { group leader }\end{array}$ & $\begin{array}{l}\text { Intsika-Yethu } \\
\text { municipality }\end{array}$ \\
\hline $\begin{array}{l}\text { Respondent 1: } \\
\text { "The municipality is very rural and there is a challenge of literacy in the area, so it } \\
\text { hinders the curiosity of people, they do not want to be associated with ICT". }\end{array}$ & Government leader & $\begin{array}{l}\text { Intsika-Yethu } \\
\text { Municipality }\end{array}$ \\
\hline $\begin{array}{l}\text { Respondent 3: } \\
\text { "Most women in Emalahleni have low levels of education; some never went to school } \\
\text { and it is therefore difficult to use technology". "They speak Xhosa and } \\
\text { computers do not have their language". }\end{array}$ & $\begin{array}{l}\text { Women support } \\
\text { group leader }\end{array}$ & Emalahleni municipality \\
\hline
\end{tabular}

It further emerged from the interview that the Thusong centre situated in Cofimvaba only offers ICT services, but does not offer ICT skills training to the people. In Emalahleni municipality, the ICT container had just been installed by the time the interviews were conducted and was not yet in operation, thus, there was no ICT skills training offered in the municipality. This lack of ICT skills training at the Cofimvaba ICT centre was also established by research conducted by Lesame and Seti (2014). Moreover, the students from the University of South Africa could not access their study materials and university resources because there was no Internet service available, either from the university or the government departments which offer other services at the centre (for example, the Department of Home Affairs which provides 
identity documents and similar services). The researchers were therefore asked by the ICT centre managers to take this matter up with the university's ITC managers so that this problem could be resolved. The researchers took it upon themselves to assist the centre managers to resolve this challenge in future.

According to respondent 1, Intsika-Yethu municipality sought to find six persons who could train others in the municipality in ICT skills literacy. Only three could be found and these three had to be trained in another bigger town, Queenstown or Lukhanji, where there are functional ICT services and business organisations.

There are no programmes (computer software) at the Intsika-Yethu municipality designed to assist women in obtaining ICT skills. Those with high incomes easily access ICT compared to those with little income, hence the skills gap in this community. That is, some women lack what Van Dijk (2008) calls access skills to search, select and process information in computer and network sources. Furthermore, some are incapable of working with software and hardware. The digital divide is therefore not closing in this municipality as a result of differences in ICT literacy and skills levels. This is mainly caused by lack of income which would enable the women to access and use ICT, as well as the absence of an ICT infrastructure itself.

\subsection{Theme 2: Universal service and access to information and communication technology}

Accessibility of ICT is a challenge to some women in South African rural areas in general and this study sought to find out the degree of ICT access in Emalahleni and Intsika-Yethu municipalities. The South African government adopted the Telecommunications Policy in 1996, through the Telecommunications Act No. 103, to pursue the goal of universal service to telecommunications services, with values which "promoted equal access to telecommunication services or universal service to these services, whether one resides in an urban or rural area" (Lesame, Mbatha \& Sindane, 2011:206). The responses obtained from the research participants show that neither the goals of the Telecommunications Policy of 1996 nor those of the 2013 Broadband Policy have been achieved.

The researchers also found that in Intsika-Yethu women are facing similar challenges as those faced by the Emalahleni women. Respondent 1, a government leader from Intsika-Yethu municipality said the following in this regard:

Usage of ICT is quite a big challenge because the municipality is rural, very few women have access to ICT and also only women working in government institutions are privileged to have access to ICT.

The above response shows that there is an ICT access gap in both Emalahleni and Intsika-Yethu due to different levels of education and income; some women rely on government social grants and a few are employed at government institutions. Those who work at government institutions easily access ICT compared to other women in the community, hence the physical access gap in the same society. These findings support the digital divide theory as argued by Fuchs and Horak (2008) who state that the income gap also creates a social divide between the working class who can afford computer and Internet access and those who cannot.

Physical access to ICT infrastructure in both Emalahleni and Intsika-Yethu is limited. Respondent 1 from IntsikaYethu stated that there was only one Thusong centre in the municipality which is located at Cofimvaba and has ten computers. The Thusong centre offers ICT services to 21 wards, that is, about 200 villages. According to respondent 2, a women support group leader, there is an ICT centre in Tsomo, although the centre is "not a multipurpose community centre", which could mean that most services are actually not available (for instance the Internet) although printed signs inside the venue indicate that there are such services.

By the time the interviews had been conducted, three ICT containers were delivered, one in Indwe, one in Lady Frere and the other one in Dordrecht. These small towns make up Emalahleni municipality. According to respondent $3, a$ government leader, the ICT centres were not yet functional. Previously, there were no ICT centres in Emalahleni, making it difficult for the people to access ICT services, and they needed to travel to Queenstown to access these services.

According to respondent 4, a government leader, Emalahleni comprises 17 wards, which is more than 200 villages, excluding farms. The Thusong centres are too few to cater for the entire municipality. The farms are mostly owned by white farmers, most of whom have working and advanced ICT services of their own. Though the world leaders made a commitment at the 2007 WSIS, to "turn the digital divide into a digital opportunity for all" (United Nations Millennium Development Goals for 2015, 2000), inadequate physical access in Emalahleni and Intsika-Yethu socially excludes the rural dwellers from the information society. Most people in these municipalities rely on government social grants, and so they cannot afford a computer and Internet connection at home. As a result, large numbers of people in the community are excluded from sophisticated e-development, due to limited or no access to advanced communications at household level (Abrahams \& Goldstuck, 2010).

Accessibility to ICT is also a major concern at secondary schools were the study was conducted. Literacy does not only refer to the ability to read, write and count, but it also refers to knowledge of computers or computer skills. 
Furthermore, computers are becoming compulsory tools in education and have made global education possible. In the Eastern Cape, computers are unavailable to many citizens and this is a challenge government needs to address urgently. In other provinces such as Gauteng and KwaZulu-Natal, this challenge is being addressed through ICT delivery to schools by public (government) and private sector partnerships or interventions. The use of computers and the Internet is increasing in the education sector in South Africa, for instance, the KwaDukuza Resource Centre in KwaZulu-Natal enables rural learners to learn about and use ICT, thereby enhancing computer literacy (Chisango, 2013). This is not the case with many learners in Intsika-Yethu and Emalahleni who are not yet part of the information society.

From the focus group interviews conducted at Cofimvaba and Gcinubuzwe senior secondary schools, it was found that the schools are producing pupils who lack computer skills which makes it difficult for them to easily adapt to the world of technology.

Pupils at both Cofimvaba and Gcinubuzwe secondary schools said that there are computer laboratories at their schools. However, not all of them have access to the computers. At Cofimvaba secondary school, not all learners are taught computer application technology (CAT); and only three classes out of 21 are CAT learners. The pupils are also not allowed to use cell phones on the school premises, and the cyber laboratory may only be used by CAT learners.

At Gcinubuzwe secondary school, computers are available but no learner uses them and they are also not used during the teaching-learning process. Furthermore, the computers are not connected to the Internet. One learner said the following:

I was at a school where I was learning computers, but now I am here, I am no longer doing them.

The pupils at Gcinubuzwe secondary school are highly disadvantaged and this widens the digital divide in this community. The learners are aware that some students are using ICT at their schools and that they will be at a disadvantage at tertiary level. Therefore, according to the ITU IDI index sub-skills, this part of South Africa is still not part of the information society. The scenario at both secondary schools is not in line with the government's e-education policy which states that:

Every South African manager, teacher and learner in the general and further education and training bands will be ICT capable (that is, use ICT confidently and creatively to help develop the skills and knowledge they need as lifelong learners to achieve personal goals and to be full participants in the global community) by 2013.

Instead of closing the digital divide, schools are actually widening the gap between the information haves and the information have-nots. It is at school where a learner, regardless of social background, is supposed to be exposed and taught computer, Internet and other ICT skills.

The challenges that pupils at Cofimvaba and Gcinubuzwe secondary schools are facing may be a result of inadequate learning resources that incorporate ICT usage and limited technology infrastructure.

The Government Gazette No 26734 (2004) states that if every South African is to participate effectively in the global economy, no one should be socially excluded and ICT should be made available to all. Yet, research participants from Gcinubuzwe secondary school stated that there are no computer laboratories in the surrounding communities. The pupils are thus not able "to tap into the mainstream of information and knowledge, where they learn and play, expand their imagination and creativity, and collaborate with their peers across the African continent and the world" (The World Bank Group, 2007). Libraries are also not found at schools and in the community. The lack of libraries makes it tough for pupils to conduct research for their studies and they rely on teachers who is generally not that knowledgeable about everything. Therefore, the students and other people in their community are socially excluded from the information ring.

Furthermore, at Gcinubuzwe secondary school a research participant said that they travel to Lady Frere for ICT services, such as faxing and the Internet, and they are sometimes forced to travel as far as Queenstown (Lukhanji), which costs R60 (about US\$6) return, if there is no network in Lady Frere. It is thus expensive to travel long distances to access ICT services. One respondent said that they pay R20 to travel to and from Lady Frere and others pay R14 return to Lady Frere. Although ICT is supposed to compress space and time, the rural population is forced to travel long distances in order to connect to others, due to the unavailability of ICT services in the area of the research study.

The researcher also heard from the participants at Cofimvaba secondary school that some villages in the IntsikaYethu municipality do not have electricity, for instance Gqogqorha, Ntsume and Tsakane. The people living in these villages cannot charge their cell phones, watch television or do anything which requires electricity. School learners suffer because they cannot study at night. Therefore, "irregular or non-existent power supplies act as significant barriers to access and use of ICTs, particularly in rural areas" (SOAWR Policy Brief for 14 $4^{\text {th }}$ Ordinary African Union Summit, 2010:9).

It also emerged from respondent 2, a women support group leader in Intsika-Yethu municipality, that teenage 
pregnancy is an issue affecting girls, and this creates another gender digital divide. There is also drug and alcohol abuse in the municipality. Pupils drop out of school where ICT skills are taught and they become part of the information havenots in society. Thus information and communication technology physical access gaps create a society where some citizens cannot fully participate in social, economic and political issues which affect them.

\subsection{Theme 3: ICT literacy level among rural women}

The first sub-research question sought to ascertain the level of ICT literacy among rural women in the Eastern Cape.

It emerged that the majority of women in both Intsika-Yethu and Emalahleni have low levels of ICT literacy. Respondent 1, a government leader from Intsika-Yethu said that:

The municipality is very rural and there is a challenge of literacy in the area, so it hinders the curiosity of people, they do not want to be associated with ICT.

This was echoed by respondent 3, a women support group leader, who said that most women in Emalahleni had low levels of education; some never went to school and it was therefore difficult for them to use technology.

This points to the fact that some women are not motivated to use ICT because of low levels of education which Van Dijk (2008) calls motivational access. For one to have the three strategic ICTs - the mobile phone, Internet and computer - ICT literacy is a requirement. Therefore, the low level of education among the women in both Intsika-Yethu and Emalahleni presented a challenge to the uptake and use of ICT.

Respondent 4, a government leader, also from Emalahleni said the following:

With the ICT, the main language on the computer is not our language, remember our home language is Xhosa and a few Afrikaans and English, and so it does affect them.

Rural women often only know their mother tongue and the language used in ICTs is foreign to them which makes it even more difficult for the ICT-illiterate women to embrace technology. Thus language barriers add a digital divide in society; those who cannot understand the language on the Internet cannot make any meaningful use of it. Low literacy levels in a community might mean low chances of finding employment, as well as low entrepreneurship skills resulting in poverty in this society.

\subsection{Theme 4: Affordability of ICT to rural women}

Information and communication technology services are not for free, therefore the researcher examined how affordable ICT is for the ordinary rural women. Low incomes coupled with low levels of education are barriers to ICT. For anyone to be able to afford a computer, the Internet or a mobile phone, a stable income is required.

Most women in Intsika-Yethu and Emalahleni are finding it difficult to use ICTs because they are expensive. Respondent 3, a women support group leader from Emalahleni said that:

Most women are so poor; they do not have their own Internet.

All the research participants in the study said that most people in both municipalities are poor and they rely on government social grants, such as child grants and old age pensions, as a source of income. The majority of the women do not work and the money that they obtain from social grants is not enough to buy food and clothes. Thus any ICTs such as laptops, modems and printers are completely out of their reach.

Some girls at Gcinubuzwe secondary school said that they work in town during the school holidays so that they earn money to buy cell phones. Respondent 4, a government leader, also mentioned that not all women have a mobile phone - "remember one has to buy the cell phone". Furthermore, the girls at Gcinubuzwe said that most parents buy the cheap cell phones and as a result "we cannot access all the information". Such cell phones do not have all the enhanced applications such as an internet connection required by school pupils.

This makes it impossible for children to research and even socialise with others through social networks, hence they are cut off from the global culture. Furthermore, the price for fixed broadband is high in developing countries, limiting access to the information society (ITU World Telecommunication/ICT Indicators database 2009). Most poor people are thus limited to voice and text messaging. 


\subsection{Theme 5: Possible approaches to overcome technology challenges in rural areas}

The theme on possible approaches was developed in an attempt to address the challenges that are faced by some rural women in the uptake and usage of ICT. Possible solutions were sought from the research participants.

Respondent 1, a government leader, and respondent 2, a women support group leader, both from Intsika-Yethu, articulated that the community should be trained in basic ICT skills so that they could help themselves and their families. The respondents said that some have cell phones connected to the Internet, but they cannot assist their children with homework.

Advocacy is another possible solution that was suggested by respondent 4, a government leader from Emalahleni. She said that some women have smart phones but are unaware of the programs on their phones, so advocacy is a necessity. Information on health issues, weather forecasts and e-mail could be accessed via mobile phones.

According to respondent 3, a women support group leader from Emalahleni, women who lack ICT skills should seek help from those who have the knowledge. She also said that women's forum groups should make the special programmes manager of the municipality aware of their problems regarding ICT use in the community.

Learners at both Gcinubuzwe and Cofimvaba secondary schools believed that the Department of Education should make sure that all learners are taught CAT. At Gcinubuzwe, the research participants felt that an Internet connection would be of great help to the school. It would make their studies a lot easier and at the same time prepare them for the world of work.

At Cofimvaba senior secondary school, the school girls mentioned that libraries should be made available in villages because pupils who attend school there do not have access to libraries. Furthermore, the girls stated that the libraries should also have computers connected to the Internet.

The research participants at Cofimvaba secondary school stated that some villages in Intsika-Yethu did not have electricity. This is despite the fact that access to electricity had improved to $73,9 \%$ in the Eastern Cape in 2011, according to the national census (Statistics South Africa, 2011: 62) (see Figure 6).

Figure 6: Percentage of households that use electricity for lighting: Census 1996, 2001, 2011 and Community Survey (CS) 2007

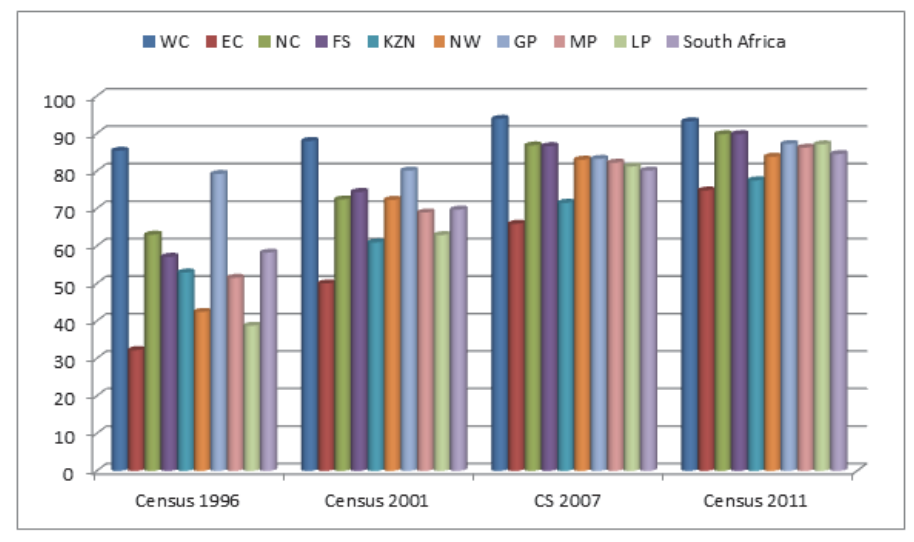

\begin{tabular}{|c|c|c|c|c|c|c|c|c|c|c|}
\hline & WC & EC & NC & FS & KZN & NW & GP & MF & LP & South Africa \\
\hline Census 1996 & 85.4 & 32.2 & 63.0 & 57.1 & 52.9 & 42.2 & 79.2 & 51.5 & 38.7 & 58.2 \\
\hline Census 2001 & 88.0 & 50.0 & 72.4 & 74.4 & 60.9 & 72.3 & 80.1 & 68.9 & 62.9 & 69.7 \\
\hline CS 2007 & 93.9 & 65.9 & 86.8 & 86.6 & 71.5 & 83.0 & 83.3 & 82.2 & 81.2 & 80.1 \\
\hline Census 2011 & 93.2 & 74.8 & 85.1 & 89.8 & 77.5 & 83.8 & 87.2 & 86.2 & 87.1 & 84.5 \\
\hline
\end{tabular}

Source: Statistics South Africa (2011)

Figure 6 shows that access to electricity in the Eastern Cape has improved between 1996 and 2011, although the percentage is still lower compared to that in the other provinces. Abbreviations in Figure 6 represent the nine provinces of Western Cape (WC); Eastern Cape (EC); Northern Cape (NC); Free State (FS); KwaZulu-Natal (KZN); North West (NW); Gauteng (GP); Mpumalanga (MP); and Limpopo (LP). The lack of electricity could be addressed by using gas and solar 
power. Although an ICT cannot, for example, charge a mobile phone with gas but one can read a book and access education if solar power and gas exist in an area.

\section{A Critique of the Universal Service and Access Agency of South Africa}

The Universal Service and Access Agency of South Africa (USAASA) was established through the Telecommunications Act of 1996 to ensure that "every man, woman and child whether living in the remote areas of the Kalahari or in urban areas of Gauteng can connect, speak, explore and study using ICT" (Universal Service and Access Agency of South Africa, 2013). The findings of this study indicate that the USAASA has failed to fulfil its mandate of "promoting universal access and universal service" (van Audenhove, 1999) in both local municipalities. Not every learner is able to study using ICT because of access challenges, that is, unavailability of the Internet at some schools and inadequate computers to cater for all learners, thus perpetuating education marginalisation.

Failure by the USAASA to provide adequate ICT in the two municipalities prevents some of the locals from fully exercising their fundamental human rights enshrined in the 1996 South African Constitution - that is, the right to communicate (Constitutional Law Act, No. 108 of 1996).

Research findings indicate that some community members of Cofimvaba cannot easily access the only multipurpose community centre in Cofimvaba due to cost, low levels of ICT and distance. The scenario is even worse in Emalahleni which did not have a functional Thusong service centre at the time the research was conducted. There are no ICT skills training programmes in both Intsika-Yethu and Emalahleni. The low-income, isolated and disadvantaged residents are thus excluded from the information society.

The Eastern Cape provincial government could collaborate with other stakeholders, such as universities, civil society, communications industry, business, and global development partners (Lesame, 2013). Rhodes and Fort Hare universities collaborate with the Dwesa community of Amathole district in the Eastern Cape through their Telkom Centre of Excellence, providing locals with ICT training, e-commerce and innovative ways of making information available to the locals (Eliasz \& von Staden, 2008; Lesame \& Seti, 2014). A similar project could be set up in the CHDM where ICT skills training is needed by schools and the community.

\section{Limitations of the Study}

The study was conducted in two local municipalities, under the CHDM, in the Eastern Cape. The research findings cannot be generalised to other municipalities in the rest of South Africa. The researchers only used two qualitative data collection methods, yet other methods could have been used had there been more time and financial resources available.

\section{Recommendations for Future Policy Interventions and Directions as well as Community Engagement Research}

Against the research findings and the findings from the literature review, the following recommendations are made:

\subsection{Designing intervention programmes for school learners}

The Eastern Cape provincial government should design an ICT strategy for the province, and local municipalities need to implement the strategies in the communities. The National Department of Education should make it policy that all learners from primary to senior secondary school are taught and examined on ICT skills. Computer application technology and information technology should be made compulsory subjects in schools. Access for all should be ensured at schools; access to computers should be increased at schools so that all learners are able to use ICTs for educational programmes. A computer literacy program for educators in South Africa, together with the provision of programs required in the teaching learning process and measures to protect the infrastructure, is recommended. The Department of Education at provincial and district levels should conduct the ICT literacy program for teachers at school.

\subsection{Designing intervention programmes for rural women}

The Eastern Cape provincial government needs to design an ICT strategy for its municipalities. TSCs should be easily accessed in rural areas; they should be installed in wards by the USAASA and other stakeholders, such as non-profit organisations, which fund ICT projects. Information and communication technology skills should be taught to all 
disadvantaged people. Local municipalities could work with science and technology institutions such as the Meraka Institute which provides training, technical implementation and monitoring of the projects (Eliasz \& von Staden, 2008). The government could subsidise ICT services and tools so that even the poorer members of the community are able to use ICT services. It should be ensured that e-government services are offered in the local language where necessary.

Furthermore, the community ICT centres should be made relevant to the community, that is, electronic networks should meet the needs of the communities, such as information on agriculture, markets and health. Also, the community should be familiar with the language on the computer - local users should promote and use their own languages on computers.

The local community should also take part in the design, implementation and management of the TSCs; this would enable them to influence decisions which will ultimately affect them. The involvement of the locals might even yield better results from the TSCs. Community participation usually builds a sense of ownership.

\subsection{Monitoring and evaluating ICT programmes in rural areas}

The government should evaluate the effectiveness of ICT policies already in place. Measures should be put in place to monitor and support ICT projects in rural areas. The provincial government could also involve academic institutions in monitoring and evaluating ICT projects. Universities such as Rhodes and Fort Hare have students doing research on village connectivity, which will provide insight into the effectiveness of ICT programmes in the communities (Eliasz \& von Staden, 2008). The community should also participate in the evaluation of ICT projects.

Technology is a catalyst for the social and economic development of rural areas. Information and communication technology could be used to improve the lives of women in particular by providing market information for their agricultural produce, weather reports and cell phone banking access.

\subsection{Importance of the study and implications for further research}

This study was confined to Emalahleni and Intsika-Yethu local municipalities in the Eastern Cape. This study attempted to uncover the challenges faced by rural Emalahleni and Intsika-Yethu municipalities and how these challenges can be resolved. The challenges include accessibility, affordability and availability of ICTs. The study also gathered solutions to the challenges faced by the rural women. Recommendations included the need to improve ICT access and equip all citizens with ICT skills.

\section{Conclusions}

The study results revealed that some rural women in Emalahleni and Intsika-Yethu are facing massive challenges in their uptake and use of ICT. Issues of affordability, accessibility, availability and Iow ICT literacy levels are hampering the women in their desire to use ICTs. Furthermore, it was found that not all women have mobile phones; this contradicts the often stated data that South Africa has a mobile penetration rate of almost $100 \%$. These challenges perpetuate the chronic digital divide in South Africa. There are government policies in place regarding information and communication technology, but they have not yet been fully implemented in some parts of the communities where this study was conducted.

Being disconnected from an information society also means failure to acquire information on farming, markets, health and other social and political issues. The economy of the municipalities under study remains relatively underdeveloped due to a largely unskilled labour force, unaffordable ICTs and low ICT skills. South Africa remains two worlds in one, with some able to enjoy the benefits of connectivity, while others remain isolated and disconnected.

\section{References}

Abrahams, L. \& Goldstuck, A. 2010. The state of e-development in South Africa: A view from the end of the first decade of the 21 st Century. Link Public Policy Paper No 11.

Adera, E.O., Waema, T.M., May, J., Mascarenhas, O. \& Diga, K. 2014. ICT Pathways to Poverty Reduction. Ottawa: Independent Development Research Centre \& Practical Action Publishing.

Babbie, E. \& Mouton, J. 2010. The practice of social research. South African edition. Cape Town: Oxford University Press Southern Africa.

Bryman, A. 2012. Social research methods. $4^{\text {th }}$ edition. Oxford: Oxford University Press.

Carrim, Y. 2013. South African Broadband Policy: Creating Opportunities, ensuring Inclusion. Pretoria: Department of Communications. 
October, 25. Available at: http://www.gov.za/speeches/view.php?sid (accessed on 12/12/2013).

Castells, M. 2000. Materials for an exploratory theory of the network society. British Journal of Sociology, 51(1):5-24.

Chisango, G. 2013. Technology challenges faced by rural women in Eastern Cape Province: A Chris Hani District Municipality Case Study. Pretoria: University of South Africa. Master of Arts Degree Unpublished Thesis.

Chris Hani District Municipality. 2011. Sustaining growth through our people. Available at: www.chrishanidm.gov.za_accessed on 04/09/2013).

Chris Hani District Municipality. 2012-2017. Five year IDP Final Draft. Sustaining growth through our people. Available at: http://www.chrishanidm.gov.za/download/Budget\%20Documents/CHDM520Adopted\%20Final\%Retrieved on 01/05/2014.

Du Plooy, G.M. 2009. Communication research techniques, methods and applications. $2^{\text {nd }}$ Ed. Cape Town: Juta.

Eliasz, T. \& von Staden, R. 2008. Dwesa village connection business modelling feasibility analysis. Ungana-Afrika: Cooperation framework innovation systems between Finland and South Africa. www.ungana-afrika.org/sites/default/files/documents/ dwesa_business_modelling_reports.pdf Retrieved on 09/10/2013

Emalahleni local municipality. 2010. Integrated Development Plan Review 2010/11. http://www.mfma.treasury.gov.az/...\%20Integrated\% 20Development\%20Plans/2...Retrieved on 10/09/2012

Emalahleni local municipality: Emalahleni spatial development framework. 2010. Phase 2: Spatial analysis. http://drupa16dev15. enconsultant.co.za Retrieved on 04/05/2014.

Engcobo Municipality: Review of Local Economic Development Strategy and Implementation PlanFinalReport.2010. http://www.drupa16 dev15econsultant.co.za Retrieved on 11/09/2012.

Flor, A.G. 2001. ICT and Poverty: The Undisputable Link. Bangkok: Asian Development Forum and Asian Development Bank.

Fuchs, C. \& Horak, E. 2008. Africa and the digital divide. Telematics and Informatics, 25(2):99-116.

Hacker, K.L. \& Mason, S.M. 2003. Ethical gaps in studies of the digital divide. Ethics and Information Technology, 5:99-113.

Haffajee, F. 2014. 20 years, two stories: The review of our two decades of freedom is an antidote to the "things fall apart" narrative, but what does it leave out? City Press March 16: 21.

Hilbert, M. 2011. Digital gender divide or technologically empowered women in developing countries? A typical case of lies, damned lies, and statistics. Forum, 34(6) 479-489. www.globalgender.org Retrieved on 08/01/2013

Integrated Development Plan Review: Chris Hani District Municipality 2010/2011

mfma.treasury.gov.za/...\%20Integrated\%20Development Retrieved on 06/05/2013.

Integrated Development Plan. 2006-2011.Engcobo Local Municipality Integrated Development Plan. http://www.drup16dev.15. econsultant.co.za/.../Ngcobo\%20LM\%20IDP\%202009...Retrieved on 10/09/2012

ITU World Telecommunication / ICT Indicators Database. 2009. ICT Facts and Figures. Available online at: http://www.itu.int/ ITU.../ict/.../Telecom09_flye...Retrieved on 06/03/2013

International Telecommunication Union. 2009. The World in 2009: ICT Facts and Figures. Geneva. www.itu.int/net/pressoffice/ backgrounders/general/pdf Retrieved on 18/09/2012

International Telecommunication Union ICT Eye. 2009. ICT Statistics Database. http://www.itu.int/ITU-D/ICTEYE/Indicators/ Retrieved on $01 / 05 / 2013$

Kucukaydin, I \& Tisdell, E. J. 2008. The Discourse of the Digital Divide: Are We Being

Co-opted? Interactions: UCLA Journal of Education and Information Studies 4(1):1-19. Retrieved online at: http://www.escholarship.org/ uc/item/85m2z8j2 Retrieved on 11 September 2013

Kwapong, O.A.T.F. 2007a. Using Information Communication Technology. International Journal of Education and Development, 2(3) 68:88.

Kwapong, O.A.T.F. 2007b. ICTs and adult education for empowerment of rural women in Africa. International Journal of Rural Studies, 14(2).

Leedy, P.D \& Ormond, J.E. 2005. Practical Research Planning and Design. 9th Ed. New Jersey: Pearson Education Inc.

Lesame, Z. 2000. The new Independent Communications Authority of South Africa: its challenges and implications for telecommunications liberalisation in the country. Communicatio: South African Journal for Communication Theory and Research 26(2):28-36.

Lesame, N. C. (ed.). 2005. New media: policy and regulation in developing countries. Pretoria: Van Schaik.

Lesame, Z., Mbatha, B. T. \& Sindane, S. 2011. New Media in the Information Society. Pretoria: Van Schaik Publishers.

Lesame, N. 2013. Vision and Practice: The South African Information Society Experience. Journal of Multidisciplinary Research 5(1):7390 , Spring.

Available at: http://wwwjmrpublication.org Retrieved on 10 August 2013 and other dates

Lesame, Z. \& Seti, V. 2014. Technology Access Centres and Community Development: The Case of the Eastern Cape Province in South Africa. Mediterranean Journal of Social Sciences 5(10): 303-317.

McCann, M. 2005. District Profile: Eastern Cape Chris Hani District Municipality (DC13). Programme of Support to Local Economic Development in the Eastern Cape. Eastern Cape Competitive Advantage Assessment and Training Support Project. http://www.thinasinako.co.za Retrieved on 06/05/2012

Millennium Development Goals Report. 2011. Assessing Progress in Africa toward the millennium development goals. http://www.un.org/ millenniumgoals.pfd Retrieved on 23/07/2013

Mottin-Sylla, M.H. 2005. The gender digital divide in Francophone Africa: A harsh reality gender and ICT network. Dakar: ENDA Third World. 
Neuman, W. 2003. Research methods: Qualitative and Quantitative Approaches. 5th ed. New York: Pearson Education. Neuman, W.L. 2006. Social Research Methods Qualitative and Quantitative Approaches. 4th ed. New York: Allyn and Bacon.

Nieman, R., Niemann, R., Brazelle, R., Van Staden, J., Heeyns, M. \& De Wet, C. 2002. Objectivity, reliability and validity in qualitative research. South African Journal of Education 20(4): 283-286.

Oosthuizen, L.M. \& Qakisa, M. 1996. New World Information Order, in Introduction to Communication: Journalism, Press and Radio Studies. Edited by LM Oosthuizen. Cape Town: Juta: 119-133.

Sassi, S. 2005. Cultural differentiation or social segregation? Four approaches to the digital divide. New Media \& Society 7(5):684-700

Online version of this article can be found at: http://nms.sagepub.com/content/7/5/684

Retrieved on 10/03/2013

Selwyn, N. 2004. Reconsidering political and popular understandings of the digital divide. New Media \& Society 6(3):341-362.

Servaes, J. 1999. Communication for Development. One World, Multiple Cultures. New Jersey: Hampton Press.

Singh, S. 2010. The South African Information Society, 1994-2008: Problems with Policy, Legislation, Rhetoric and Implementation. Journal of Southern African Studies, 36(1): 209-227.

Solidarity for African Women's Rights Policy Brief for the 14th Ordinary African Union Summit. 2010. Bridging the digital gender divide in Africa. Addis Ababa. http://www.soawr.org/resources/women_and_ICTs.pdf Retrieved on 04/03/2013

South African Government Gazette No 26734. 2004. Department of Communications. 2004. Towards Information Communication Technologies (ICT) for Rural Development Strategic Framework. Volume 470. http://www.info.gov.za Accessed on 2012/07/05

South African Network Survey. 2013. City Press May 19:8.

Spence, R. 2010. ICT, Development and Poverty Reduction - Information. The DAC Journal 6(3).http://www.oecd.org/dac

Statistics South Africa. 2007. Community Survey. Pretoria: Statistics South Africa.

Statistics South Africa. 2011. South African Census Report or Demographic Survey. Pretoria: The Digital Divide: A LIBR 562 Project. 2011. Why is the Digital Divide Important? Available at:http://562digitaldivide.wikidot.com/why-is-the-digital-divde-important Retrieved on 10 July 2013

Sowetan Newspaper. 2012. Census 2011: It's looking up for SA. October 31:12.

South African Telecommunications Act No. 103. Pretoria: Government Printers.

South African Telecommunications Amendment Act No 64 of 2001. Pretoria: Government Printers.

Statutes of the Republic of South Africa. 1996. Constitutional Law Act No. 108. Cape Town: South African Parliament.

Statutes of the Republic of South Africa- Constitutional Law. Constitution of the Republic of South Africa Act No. 108 of 1996.

www.info.gov.za/documents/constitution/1996/a108-96.pdf Accessed On 2013/10/09

The Municipal Infrastructure Investment Framework (MIIF7) for South Africa Round 7 (2009-2010). A capital investment perspective. 2011. Midrand: Information Management Unit Development Planning Division Development Bank of Southern Africa. http://www.dbsa.org Retrieved n 2012/05/06

The World Fact Book. 2013. Central Intelligence Agency. https://www.cia.gov/library/publications/the_world.../2103.html Retrieved on $04 / 03 / 2013$

United Nations Millennium Development Goals for 2015. 2000. Retrieved online from: http://www.undp.org/mdg and at: http://www.un.org/millenniumgoals/ Retrieved on 09/10/2012

Universal Service and Access Agency of South Africa. 2013. Ensuring universal access and services to ICT's. Midrand www.usaasa.org.za Retrieved on 09/10/2013

van Audenhove, L. 1999. South Africa's information society policy: An overview. Communicatio 25(1 \& 2): 15-27.

Van Dijk, JAGM. 1999. The network society: Social Aspects of New Media. 1st edition. London: Sage.

Van Dijk, JAGM. 2006. The network society: Social Aspects of New Media. 2nd edition. London: Sage.

Van Dijk, J. 2008. The Digital Divide in Europe: Draft Chapter for the Handbook of Internet Politics. London: Routledge. http//www.utwente.nl/gw/mco/bestanden/digitaldivide.pdf Retrieved on 03/07/2012

Webster, F. 1995. Theories of the information society. London: Routledge.

White, C.J. 2002. Research Methods and Techniques. Pretoria: Technikon Pretoria.

Wikipedia. 2013. Manuel Castells' Network Society. Retrieved from: http://en.wikipedia.org/wiki/Manual_Castells Retrieved on 11-032013

World Bank Group. 2007. Connecting Africa: How ICT is transforming a continent? www.worldbank.org/ict Retrieved on 17/09/2013

World Economic Forum Information Technology and Global Competitiveness Report 2012. Retrieved online from: http://www.weforum. org/issues/global-competitiveness Retrieved on 08/01/2013

World Summit on the Information Society. 2003. Background on the United Nations Millennium Development Goals. http://www.itu.int/ osg/spu/wsisthemes/UN Retrieved on 08/01/2013

Zainal, Z. 2007. Case study as a research method. Journal Kemanusiaan bil. 9, June. http://www.eprints.utm.m/8221/1/ZZainal 2007Case_study_as_a_Research.pdf Retrieved on 03/03/2013 